\title{
A STUDY ON THE VARIATION OF STRENGTH PROPERTIES OF CONCRETE WITH PARTIAL REPLACEMENT OF CEMENT USING NANO-SILICA (NS) AND FLY ASH (FS)
}

\author{
Chinnakotti Sasidhar ${ }^{1}$, G. Sujala ${ }^{2}$ \\ ${ }^{\text {I}}$ (PG Student, Department of Structural Engineering, Sree Rama Engineering College, Rami Reddy Nagar, Tirupati, \\ Andhra Pradesh, India) \\ ${ }^{2}$ (Associate Professor, Department of Structural Engineering, Sree Rama Engineering College, Rami Reddy Nagar \\ Tirupati, Andhra Pradesh, India)
}

\begin{abstract}
This paper studies the recent investigations and development of combined application of Pozzolanic additions - Nano-Silica (NS) and Fly Ash (FA) on the strength properties of concrete for subsequential growth of concrete industry. This investigation not only saves the natural resources but also controls the environmental pollution by usage of wastes. The limited work is done on partial replacement of Fly Ash and Nano-Silica in cement paste, mortar and concrete. In the present study the cement is partially substituted by 20\% and 30\% of Fly Ash and Nano-Silica 2.0\%, 4.0\% and 6.0\% by weight. To understand the application of Fly Ash and Nano-Silica various literatures have been reviewed and their influence on Compressive Strength, Bending Strength (Flexural Strength), Elastic Modulus or Young's Modulus and Tensile Strength of M35 grade of concrete is investigated. The experimental investigation results of concrete are tabulated using the combination of various proportions of Fly Ash and NanoSilica are collate with that of Controlled Concrete. The mechanical strength development and durability properties of concrete are greatly influenced because of this combined application of Nano-Silica and Fly Ash compared to the Controlled Concrete properties. The sustainable increase in the various strength characteristics of concrete prepared using Nano-Silica and Fly Ash can be accredited to the efficacious packing of colloidal particles and the need of additional binder in the application of Fly-Ash and Nano-Silica.
\end{abstract}

Keywords: Nano-Silica (NS), Fly Ash (FA), Controlled Concrete, Packing of Colloidal Particles, Compressive Strength, Flexural Strength, Split Tensile Strength, Partial Replacement.

\section{INTRODUCTION}

Concrete has been utilizing as a construction material in wide range. At present in construction, prior to strength, the durability of concrete also has importance. The least cement content to satisfy the strength and durability requirements the Indian standard code of IS 456:2000 for plain concrete design is used. This results in usage of cement in huge content. The cement production results in evolution of lots of $\mathrm{CO}_{2}$ resulting in environment degradation. By usage of alternative materials instead of cement upto certain proportion will be another solution for this problem. Earlier studies show that

the usage of Fly-Ash (FA), Ground Granulated Blast Furnace Slag, Micro Silica (MS) and Metakaoline as replaced materials which results in increases in strength and durability. By introducing Nano sized materials as a partial replacement of cement which improves the performance of cement.

Because of many experimental researches on Nano particles, Nano-Silica is available as replacing material of cement in making concrete. Nano-Silica (NS) is a Nano- sized, highly reactive nebulous silica. Because of NanoSilica particle is as small as other particles and also having very large surface area as the substitute materials, its usage comparatively intensify the concrete performance upto extensive range. This amalgamation of Nano-Silica and fly ash as a substitute material for cement has to be scrutinized. These particles are very tiny and generally allow forming a group of mass due to its large surface influence, consistent dispersion of these fine particles is a predominant thing to get results upto serviceable or advantageous results.

\section{OBJECTIVE OF THE STUDY}

The purpose of this work is to study out the influence of the combined application of Nano-Silica (NS) and Fly Ash (FA) on various strength properties of Concrete mix. To understand the behaviour of Concrete, the cement is partially replaced with Fly Ash and Nano-Silica in the proportions of $20 \%, 30 \%$ and $2 \%, 4 \%, 6 \%$ respectively. To fulfil this, M35 grade of concrete is used for experimental investigation. The study results of Compressive Strength Test, Modulus of Elasticity Test, Flexural Strength Test and Split Tensile Test with partial replacement of Pozzolanic materials are compared with the Conventional Concrete or Controlled Concrete. 


\section{EXPERIMENTAL PROGRAMME}

\subsection{Cement}

As per the specifications of code IS: 8112-1989 OPC (ordinary Portland cement) of 43grade is used for the present investigation. The cement utilized should be free of lumps and fresh and various investigations carried out should be as per Indian Standard Code specifications as shown in table-1

Table 1: Physical Properties of Cement

\begin{tabular}{|c|l|c|c|}
\hline $\begin{array}{c}\text { S. } \\
\text { No }\end{array}$ & \multicolumn{1}{|c|}{ Property } & $\begin{array}{c}\text { Test } \\
\text { result }\end{array}$ & $\begin{array}{c}\text { As per } \\
\text { IS8112:1989 } \\
\text { (Limitations) }\end{array}$ \\
\hline 1 & $\begin{array}{l}\text { Specific } \\
\text { Gravity }\end{array}$ & 3.15 & $2.5-3.15$ \\
\hline 2 & $\begin{array}{l}\text { Normal } \\
\text { Consistency }\end{array}$ & $32 \%$ & $28-35$ \\
\hline 3 & $\begin{array}{l}\text { Setting Time } \\
\text { (a)Initial } \\
\text { Setting time } \\
\text { (b)Final setting } \\
\text { time }\end{array}$ & $\begin{array}{l}120 \\
\text { minutes } \\
6 \text { hours }\end{array}$ & $\begin{array}{l}\text { Not less than } 30 \\
\text { minutes and not } \\
\text { more than } 600 \\
\text { minutes }\end{array}$ \\
\hline
\end{tabular}

\subsection{Fine Aggregates}

Available local river sand confirming to IS: $383-1970$ was used as fine aggregates in concrete preparation. The fine aggregates passing through $4.75 \mathrm{~mm}$ IS sieve is utilised as shown in table-2

Table 2: Properties of Fine aggregate

\begin{tabular}{|l|l|l|}
\hline $\begin{array}{c}\text { S. } \\
\text { No }\end{array}$ & \multicolumn{1}{|c|}{ Physical property } & $\begin{array}{c}\text { Fine Aggregate } \\
\text { Values }\end{array}$ \\
\hline 1 & Specific Gravity & 2.70 \\
\hline 2 & Fineness Modulus & 2.8 \\
\hline \multirow{3}{*}{3} & Bulk Density & $16.75 \mathrm{kN} / \mathrm{m}^{3}$ \\
& (a)Loose State & $17.15 \mathrm{kN} / \mathrm{m}^{3}$ \\
\hline 4 & (a)Compacted State & Zone $-\mathrm{II}$ \\
\hline
\end{tabular}

\subsection{Coarse Aggregates}

Coarse aggregates of nominal sizes $20 \mathrm{~mm}$ and $10 \mathrm{~mm}$ locally accessible crushed stone available from the quarries confirming to IS383-1970 was utilized in the proportion of $1.5: 1.0$ as shown in table-3

Table 3: Properties of Coarse aggregate

\begin{tabular}{|l|l|l|}
\hline S.No & \multicolumn{1}{|c|}{ Physical properties } & $\begin{array}{c}\text { Fine Aggregate } \\
\text { Values }\end{array}$ \\
\hline 1 & Specific Gravity & 2.65 \\
\hline \multirow{2}{*}{2} & Bulk Density & \\
& (a)Loose State & $13.15 \mathrm{kN} / \mathrm{m}^{3}$ \\
& (b)Compacted & $15.68 \mathrm{kN} / \mathrm{m}^{3}$ \\
\hline 3 & State & $0.3 \%$ \\
\hline 4 & Water Absorption & 7.85 \\
\hline
\end{tabular}

\subsection{Fly Ash}

For the present investigation Fly Ash of "Class-F" obtained from the Thermal Power plant is used. The Fly Ash proportions of $20 \%$ and $30 \%$ by weight of cement are used. The Physical properties of Fly Ash are as shown in table-4

Table 4: Properties of Fly Ash

\begin{tabular}{|c|c|c|}
\hline S.No. & Properties & Values \\
\hline 1 & Silica $\left(\mathrm{SiO}_{2}\right)$ & $56.87 \%$ \\
\hline 2 & Aluminium trioxide $\left(\mathrm{Al}_{2} \mathrm{O}_{3}\right)$ & $27.65 \%$ \\
\hline 3 & $\begin{array}{c}\text { Ferric oxide } \\
\left(\mathrm{Fe}_{2} \mathrm{O}_{3}+\mathrm{Fe}_{3} \mathrm{O}_{4}\right)\end{array}$ & $6.28 \%$ \\
\hline 4 & Titanium dioxide $\left(\mathrm{TiO}_{2}\right)$ & $0.31 \%$ \\
\hline 5 & Magnesium oxide $(\mathrm{MgO})$ & $0.34 \%$ \\
\hline 6 & Loss of ignition $(\mathrm{LOI})$ & $4.46 \%$ \\
\hline 7 & Specific gravity of Fly Ash & 2.12 \\
\hline
\end{tabular}

\subsection{Nano-Silica}

Nano-Silica utilised in this investigation is a Pozzolanic colloidal silica emulsion. It is a better Pozzolanic material because of its high content of Amorphous Silica (>99\%) and also their reduced spherical size of order $10 \mathrm{~nm}-50 \mathrm{~nm}$. The properties of Nano-Silica is shown in table-5

Table 5: Properties of Nano-Silica

\begin{tabular}{|l|l|l|}
\hline S.NO. & Properties & Actual results \\
\hline 1 & Nano solids & $39.5-41 \%$ \\
\hline 2 & $\mathrm{Ph}$ & $9.0-10$ \\
\hline 3 & Specific Gravity & $1.29-1.31$ \\
\hline 4 & Texture & White Liquid (Milky liquid) \\
\hline 5 & Dispersion & Water \\
\hline
\end{tabular}

\subsection{Water}

Water used for casting and curing of concrete specimens should be free from all types of contaminants like alkalis, salts, acids, organic matter, oils and other pollutants. The water with impurities can adversely influence the strength properties of concrete.

\subsection{Mix Proportions}

The mix design for M35 grade is carried out as per the specifications of Indian Standard code IS10262: 2009. The various mix proportions of constituent materials are calculated to one cubic meter of concrete. Table- 6 shows the proportion of Nano-Silica in quantity which is adjusted from its colloidal liquid form. 
Table 6: Quantities of Cement, Fly Ash and Nano-Silica per Cum of M35 grade Concrete

\begin{tabular}{|l|l|l|l|l|l|}
\hline S.No & Concrete & Water (lit) & Cement (kgs) & Fly ash (kgs) & Nano-Silica (Colloidal) (kgs) \\
\hline 1 & Control Concrete & 153 & 340 & 0 & 0 \\
\hline 2 & FA $(20 \%)+$ NS (0\%) & 153 & 272 & 68 & 0 \\
\hline 3 & FA $(20 \%)+$ NS (2\%) & 146.2 & 265.2 & 68 & 17 \\
\hline 4 & FA $(20 \%)+$ NS (4\%) & 139.4 & 258.4 & 68 & 34 \\
\hline 5 & FA $(20 \%)+$ NS (6\%) & 132.6 & 251.6 & 68 & 51 \\
\hline 6 & FA $(30 \%)+$ NS (0\%) & 153 & 238 & 102 & 0 \\
\hline 7 & FA $(30 \%)+$ NS (2\%) & 146.2 & 231.2 & 102 & 17 \\
\hline 8 & FA $(30 \%)+$ NS (4\%) & 139.4 & 224.4 & 102 & 24 \\
\hline 9 & FA $(30 \%)+$ NS (6\%) & 132.6 & 217.6 & 102 & 36 \\
\hline
\end{tabular}

\subsection{Test Specimens}

The concrete specimens are,

a) Cubes- $150 \mathrm{~mm} \times 150 \mathrm{~mm} \times 150 \mathrm{~mm}$

b) Cylinders- diameter $(150 \mathrm{~mm})$ and height $(300 \mathrm{~mm})$

c) Prisms $-100 \mathrm{~mm} \times 100 \mathrm{~mm} \times 500 \mathrm{~mm}$

The concrete specimens are tested at different curing periods (3, 7, 28 and 56days). After the curing of specimens they are tested for various mechanical strength tests at 28 days. As per the specifications of IS516:1959 the loading rate is to be carried.

\section{RESULTS AND DISCUSSION}

\subsection{Compressive Strength}

By the combined application of Fly Ash and Nano-Silica the compressive strength of cube specimens varies with Age of concrete in days as shown in fig- 1 and the strength attained is the average of three test results. It is noticed that the compressive strength attained by the combined application exhibits more than that of Controlled concrete as shown Fig1. From fig-2 it is noticed that, the cube compressive strength increases upto the combination Fly Ash (20\%) and Nano-Silica (4\%) at 7 days and 28 days as $39.70 \mathrm{MPa}$ and $55.13 \mathrm{MPa}$.

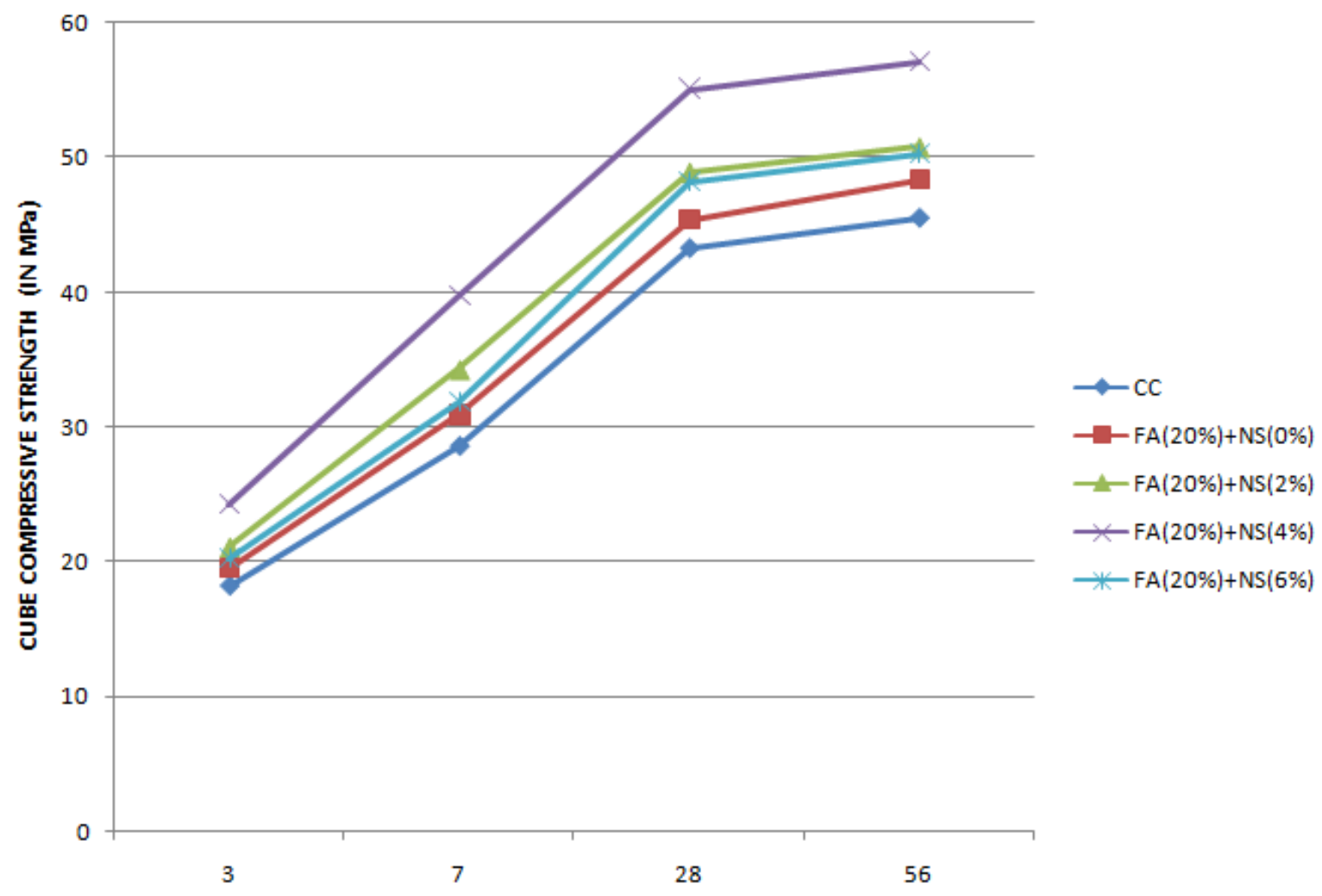

AGE OF CONCRETE (IN DAYS)

(a) Fly Ash (20\%) 


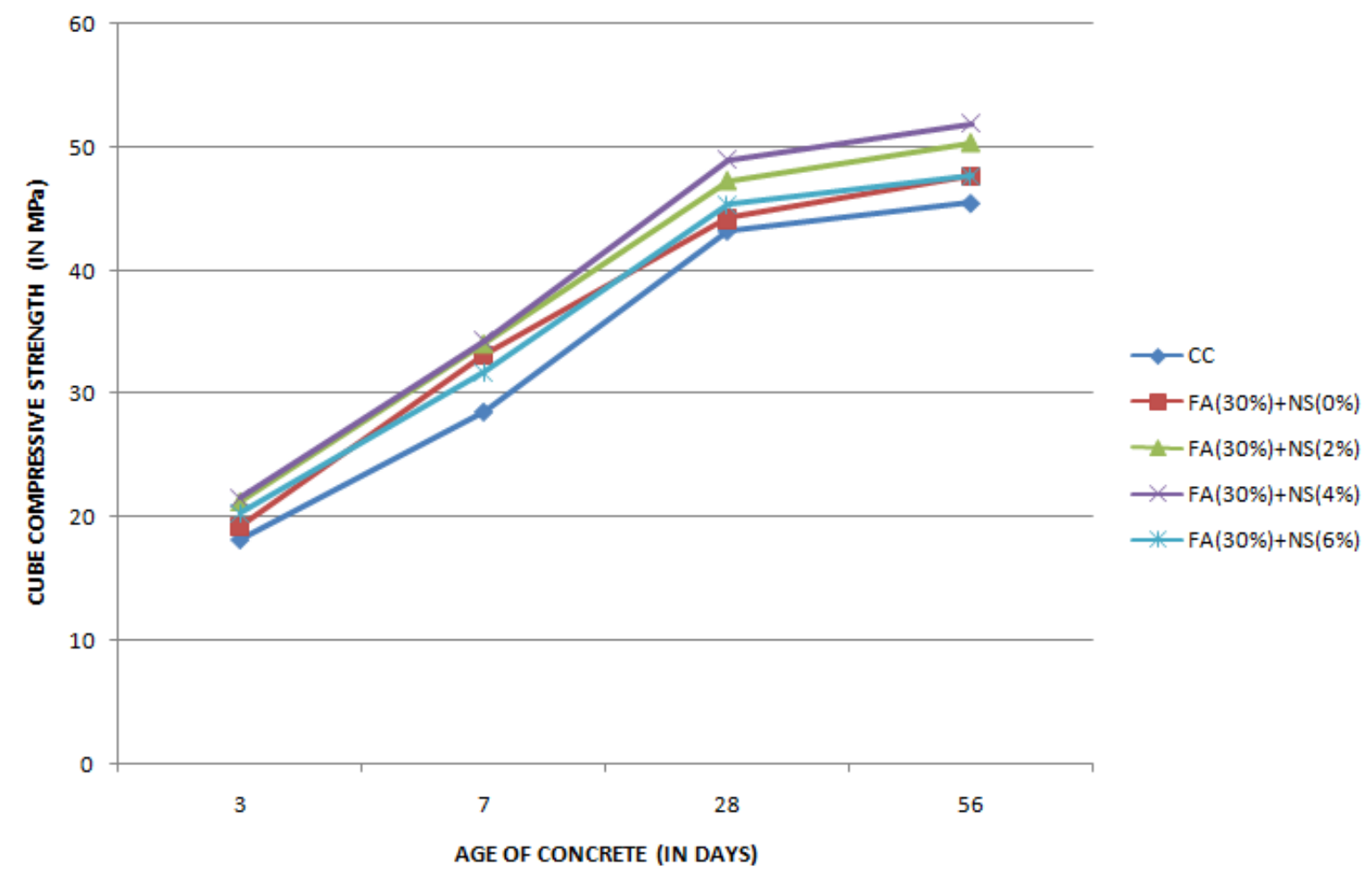

(b) Fly Ash (30\%)

Fig: 1 shows the variation of Compressive strength (MPa) for M35 Grade Concrete at various proportions of Fly Ash and NanoSilica at different Age (in Days)

From fig-2 it is noticed that, the cube compressive strength increases upto the combination Fly Ash (20\%) and NanoSilica $(4 \%)$ at 7 days and 28 days as $39.70 \mathrm{MPa}$ and $55.13 \mathrm{MPa}$. It is observed that a sudden decrement in cube compressive strength occur when Nano-Silica content is above $4 \%$.
When Fly ash (30\%) content is changed and Nano-Silica $(4 \%)$ then the compressive strength is less than the compressive strength of controlled concrete. The cube compressive strength increases upto $11.22 \%$ and $12.10 \%$ by the combined application of Fly Ash (20\%) and Nano-Silica $(4 \%)$ as shown in fig- 2 .

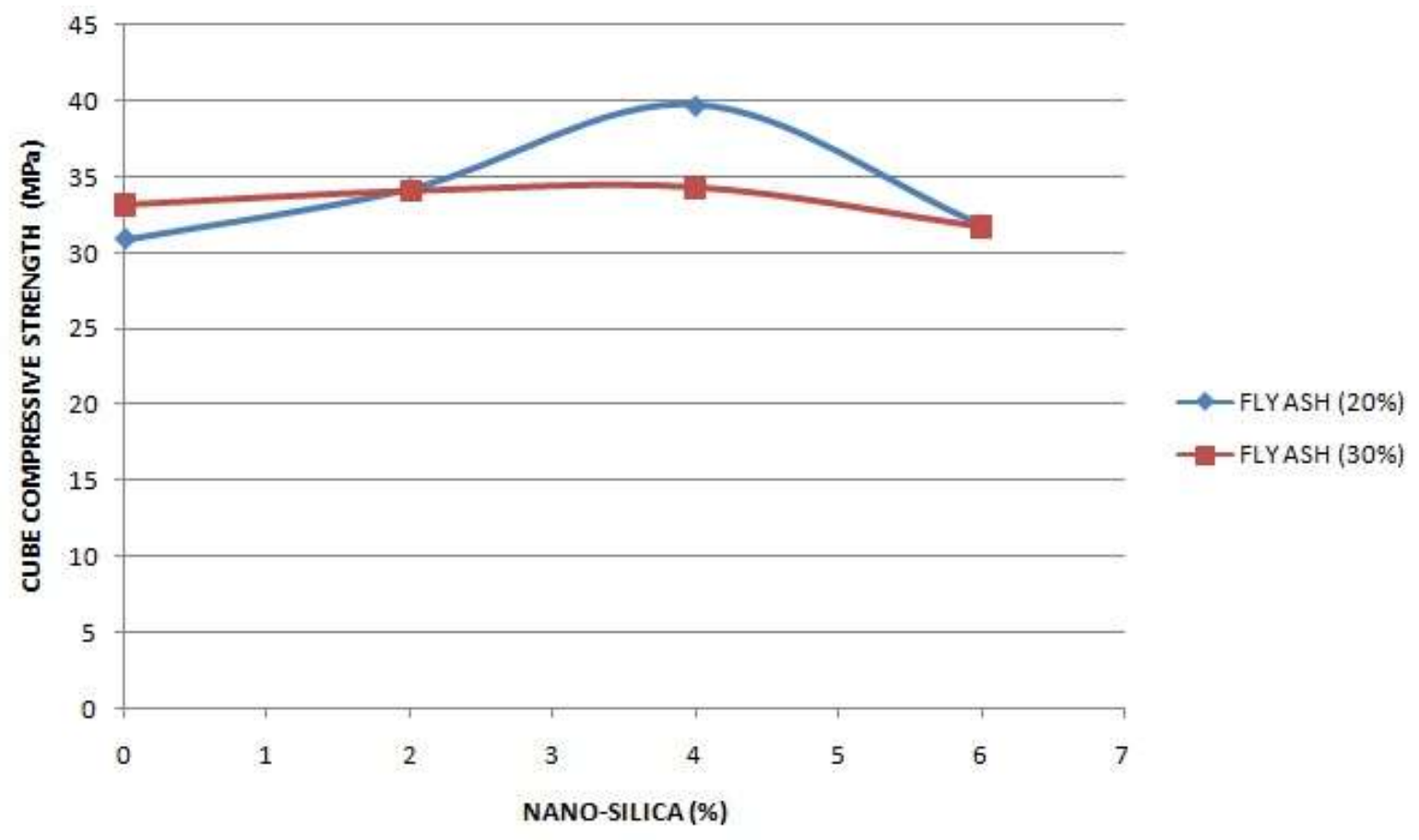

(a) 7 days cube compressive strength ( $\mathrm{MPa})$ 


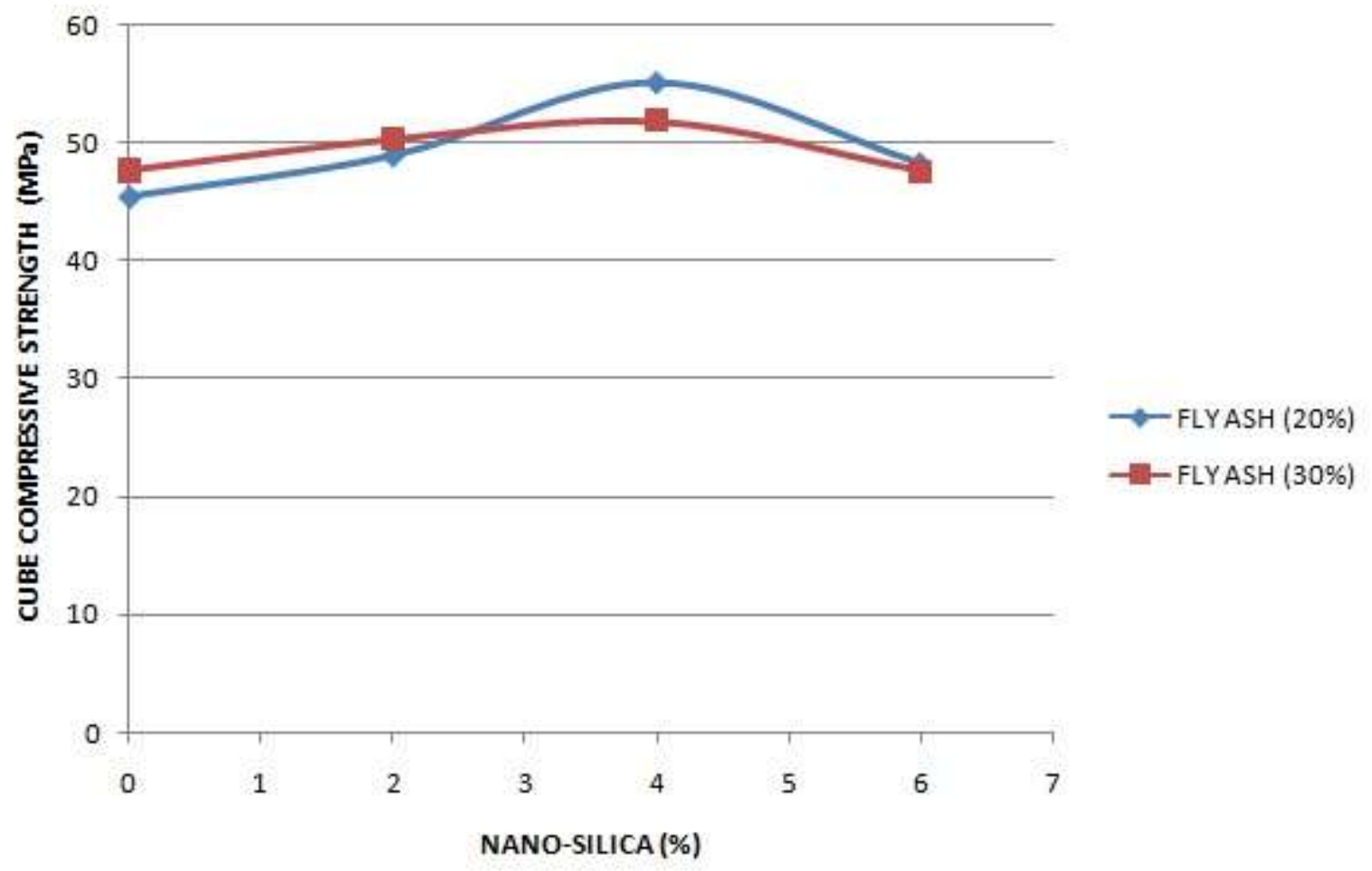

(b) 28 days cube compressive strength (MPa)

Fig: 2 Shows the variation of cube compressive strength (MPa) at 7days and 28days with Nano-Silica (\%) with various proportions of Fly Ash (\%).

Differentiating the compressive strength between cube specimen and cylinder specimen at 28days of curing of concrete specimen for various Fly Ash and Nano-Silica proportions is mentioned in table-7. The compressive strength varies between cube and cylinder around a ratio of 0.88 .

Table: 7 Shows the Differentiation of compressive strengths of Cube and Cylinder at 28days curing with various Fly Ash and Nano-Silica content

\begin{tabular}{|l|l|l|l|l|}
\hline S.No & \multicolumn{1}{|c|}{ Concrete } & $\begin{array}{l}\text { Cube Compressive Strength } \\
(\mathrm{MPa}) \sigma_{\text {Cube }}\end{array}$ & $\begin{array}{l}\text { Cylinder Compressive Strength } \\
(\mathrm{MPa}) \sigma_{\text {Cylinder }}\end{array}$ & $\sigma_{\text {Cylinder }} / \sigma_{\text {Cube }}$ \\
\hline 1 & Control Concrete & 43.25 & 37.25 & 0.86 \\
\hline 2 & FA 20 $\%+$ NS 0 $\%$ & 45.42 & 39.97 & 0.88 \\
\hline 3 & FA 20 $\%+$ NS 2.0 $\%$ & 48.92 & 43.04 & 0.88 \\
\hline 4 & FA 20 $\%+$ NS 4.0 $\%$ & 55.13 & 49.62 & 0.90 \\
\hline 5 & FA 20 $\%+$ NS 6.0 $\%$ & 48.25 & 42.46 & 0.88 \\
\hline 6 & FA 30\%+ NS 0 $\%$ & 44.19 & 37.56 & 0.85 \\
\hline 7 & FA 30 $\%+$ NS 2.0 $\%$ & 47.25 & 40.64 & 0.86 \\
\hline 8 & FA 30\% + NS 4.0\% & 48.94 & 40.79 & 0.89 \\
\hline 9 & FA 30\% + NS 6.0 $\%$ & 45.32 & 0.90 \\
\hline
\end{tabular}

\subsection{Split Tensile Strength}

For M35 Grade of concrete mix the Split Tensile Test variance is investigated for the concerned proportions of Pozzolanic substituent Fly ash and Nano-Silica and is mentioned in the form of graphical representation. The investigated Split Tensile Strength for controlled concrete is $4.14 \mathrm{~N} / \mathrm{mm}^{2}$. This strength varies gradually with the increase in Nano-Silica content upto $4 \%$ and then a sudden decrement in strength occurs with increase in Nano-Silica as shown in fig-3. It seems that the combined application of Fly ash and Nano-Silica with $20 \%$ and $4 \%$ gives extreme strength improvements and if the Nano-Silica content changes to $6 \%$ with same fly ash obtains the tensile strength as $4.39 \mathrm{~N} / \mathrm{mm}^{2}$. 


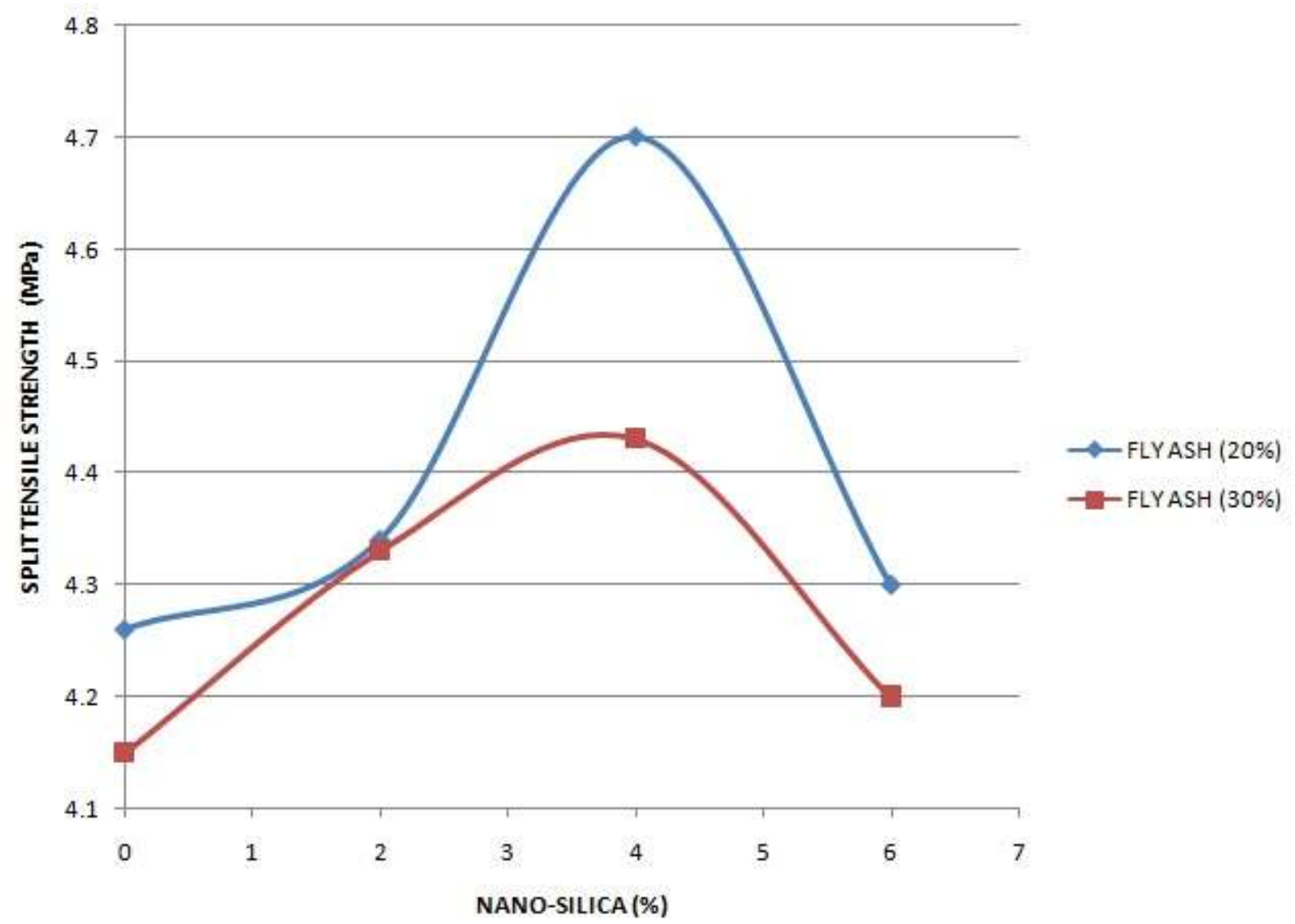

Fig: 3 Graphical variation of split tensile strength of M35grade concrete for various mix proportions of Fly ash and Nano-Silica.

\subsection{Flexural Strength}

For M35 Grade of concrete mix the Flexural Strength Test variance is investigated for the concerned proportions of Pozzolanic substituent Fly ash and Nano-Silica is mentioned in table-9. The investigated Flexural Strength for controlled concrete is $6.58 \mathrm{~N} / \mathrm{mm}^{2}$ It seems that the combined application of Fly ash and Nano-Silica with $20 \%$ and $4 \%$ gives extreme strength improvements and if the Nano-Silica content changes to $6 \%$ with same fly ash obtains the tensile strength as $7.11 \mathrm{~N} / \mathrm{mm}^{2}$. The improvement of strength by the substitution of Pozzolanic additives of Fly ash $(20 \%)$ and Nano-Silica (4\%) is $7.80 \mathrm{~N} / \mathrm{mm}^{2}$ as shown in fig-4

Table: 9 Shows the percentage variation of Flexural strength for M35 grade concrete mix for various proportions of Fly Ash and Nano-Silica

\begin{tabular}{|c|c|c|c|}
\hline \multirow{2}{*}{ Concrete Mix } & \multirow{2}{*}{$\begin{array}{l}\text { FA } \\
(\%)\end{array}$} & \multirow{2}{*}{$\begin{array}{l}\text { Nano Silica } \\
(\%)\end{array}$} & Flexural Strength (MPa) \\
\hline & & & for 28 Days \\
\hline Control Concrete & 0 & 0 & 6.58 \\
\hline FA $20 \%+$ NS $0 \%$ & 20 & 0 & 6.81 \\
\hline FA $20 \%+$ NS $2.0 \%$ & 20 & 2.0 & 7.18 \\
\hline FA $20 \%+\mathrm{NS} 4.0 \%$ & 20 & 4.0 & 7.80 \\
\hline FA $20 \%+\mathrm{NS} 6.0 \%$ & 20 & 6.0 & 7.11 \\
\hline $\mathrm{FA} 30 \%+\mathrm{NS} 0 \%$ & 30 & 0 & 6.68 \\
\hline FA $30 \%+$ NS $2.0 \%$ & 30 & .0 & 7.01 \\
\hline FA $30 \%+$ NS $4.0 \%$ & 30 & 4.0 & 7.18 \\
\hline FA $30 \%+$ NS $6.0 \%$ & 30 & 6.0 & 6.03 \\
\hline
\end{tabular}




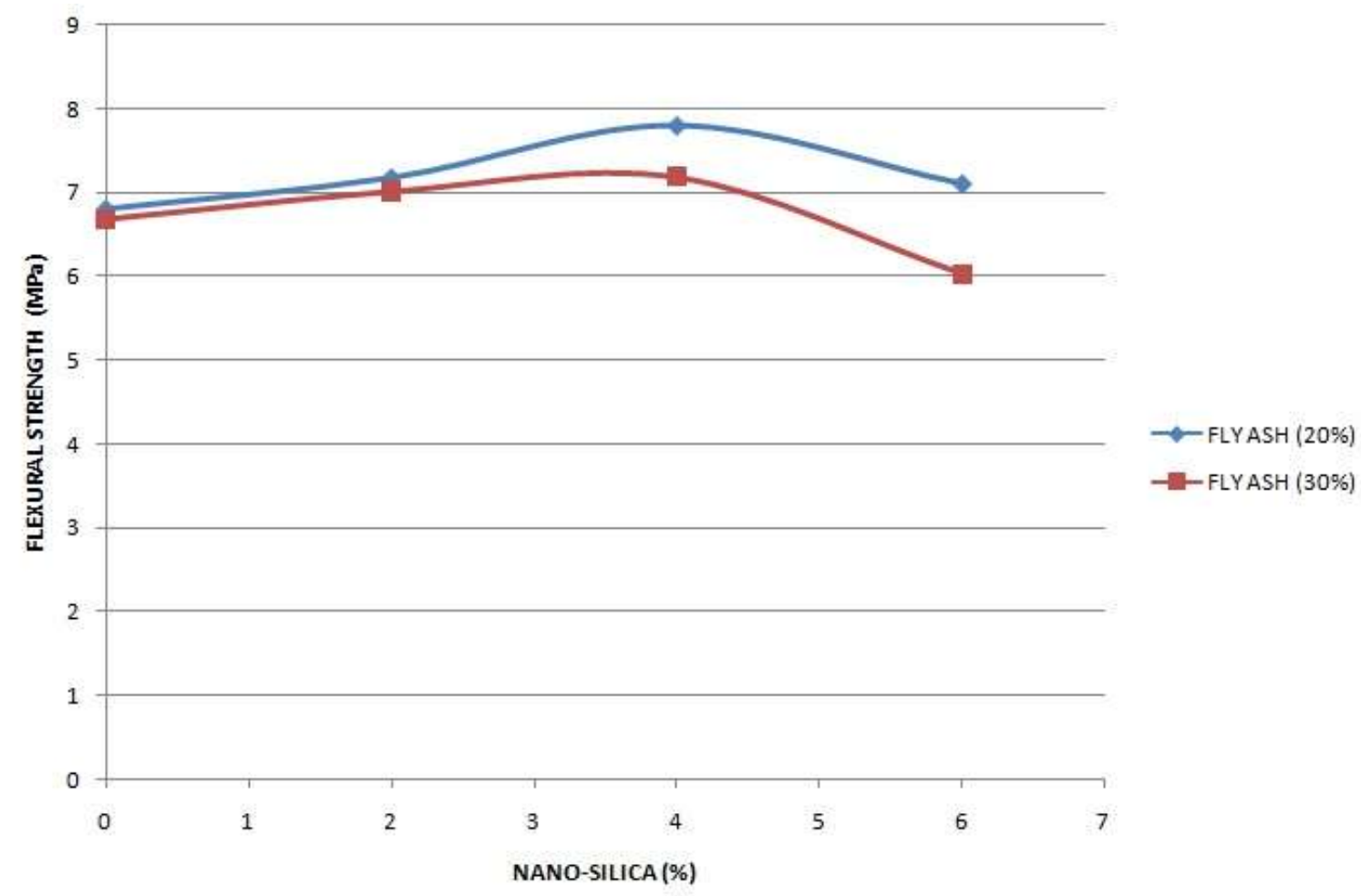

Fig: 4 Graphical variation of Flexural strength of M35grade concrete for various mix proportions of Fly ash and Nano-Silica.

\subsection{Modulus of Elasticity}

The experimental investigations on the Modulus of Elasticity for M35 grade concrete mix with varying of Fly ash and Nano-Silica are mentioned in fig-5. It is shown that the Modulus of Elasticity for controlled concrete is
32.88GPa. The increase in the Modulus of Elasticity with Fly Ash (20\%) and Nano-Silica (4\%) is $4.22 \mathrm{GPa}$ and it is the maximum value attained. If this proportion further increases to $6 \%$ of Nano-Silica then the Modulus of Elasticity decreased to $34.73 \mathrm{MPa}$ as shown in fig-5.

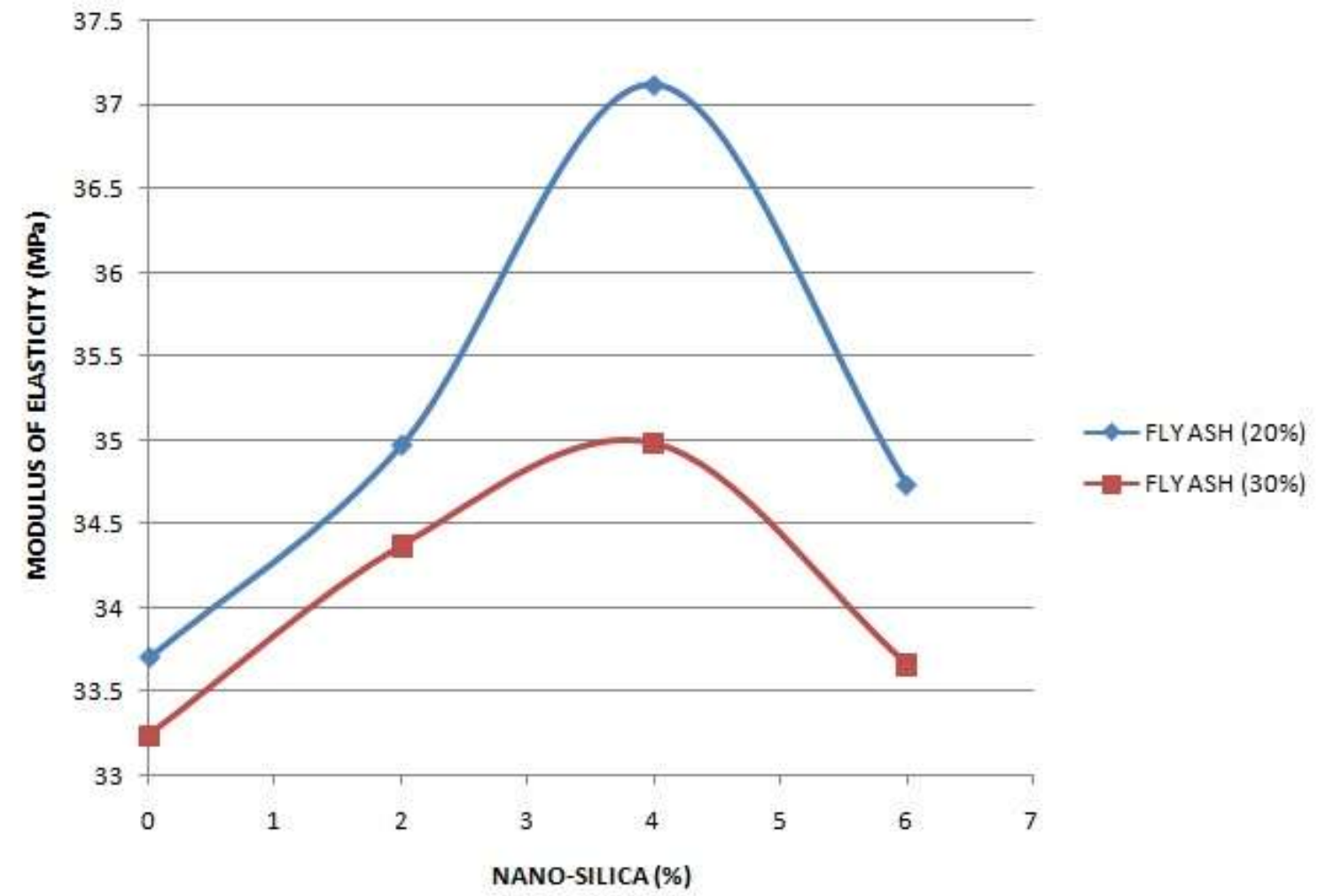

Fig: 5 Graphical variation of Modulus of Elasticity of M35grade concrete for various mix proportions of Fly ash and Nano-Silica. 


\section{CONCLUSION}

From the investigation results i.e., a partial replacement of cement with Fly Ash and Nano-Silica it is studied that various strength properties of concrete mix increases upto $4 \%$ application of Nano-Silica content and decreases with further increment. It is quite enthusiastic observation that the changes occurred in the strength properties like compressive strength, tensile strength and flexural strength with change in cement proportion. Due to the presence of additional binder which is formed by the combination of Fly ash and Nano-Silica with Calcium hydroxide substantially increases the strength properties of concrete. Because of additional binder formed in concrete due to the Pozzolanic additives tends to form a paste-aggregate bond which leads to increment in the strength properties of concrete. The partial replacement of Fly ash and Nano-Silica tends to give maximum increment in strength properties at Fly ash content $20 \%$ and Nano-Silica content $4 \%$. But the decrement in the strength properties with increase in Nano-Silica content is due to the formation of poor quality binder.

\section{REFERENCES}

[1]. Thomas et.al.,(1999), "Reported that fly ash reduced concrete strength at early ages, but significantly enhanced strength at later ages". Cement and Concrete Research, Vol 29(4), pp.487- 495.

[2].Gengying Li.,(2004). "Properties of High-Volume Fly Ash Concrete incorporating Nano-SiO2", Cement and Concrete Research, pp. 1043-1049.

[3].Jagadesh.Sunku (2006), "had studied the advantages of use of fly ash as Supplementary Cementing Materials in Fibre cement sheets. International Inorganic Bonded Fibre Composites Conference, pp.25-32.

[4].Belkowitz,J. and Armentrout, D. L. (2009). The Investigation of Nano Silica in the Cement Hydration Process. ACI Special Publication 267(8): 87-100.

[5].IS: 10262-2009. Concrete Mix Proportioning Guidelines (First Revision). Bureau of Indian Standards, New Delhi.

[6].IS 516:1959. "Methods of Tests for Strength of Concrete". Bureau of Indian Standards, New Delhi, India.

[7].IS: 8112:1989. "43 Grade Ordinary Portland Cement Specifications". D.P. Bentz et al.,(2010), "studied the evaluation of sustainable high volume fly ash concretes, Cement and Concrete Composites, Vol 33, pp 3945. 